Brit. J. industr. Med., 1962, 19, 52.

\title{
THE ATTACK RATE OF PROGRESSIVE MASSIVE FIBROSIS
}

\author{
BY \\ A. L. COCHRANE \\ From the Pneumoconiosis Research Unit, Llandough Hospital, and Department of Tuberculosis and \\ Chest Diseases, Welsh National School of Medicine, Sully Hospital, Glamorgan
}

(RECEIVED FOR PUBLICATION MARCH 7, 1961)

A radiological follow-up of the miners and ex-miners in two Welsh mining valleys whose chest radiographs showed simple pneumoconiosis in 1950/51 has been carried out to study the factors associated with the attack rate of progressive massive fibrosis. The radiographs were read in pairs, and also with the pairs separated, the radiographs being randomized and identifying features concealed. The relative value of these two types of reading is discussed.

An attempt to investigate the importance of exogenous tuberculous infection by comparing the attack rate in the two mining valleys, in one of which great efforts had been made to eradicate tuberculosis, failed. The reasons for the failure are discussed.

No evidence was found of any association between the attack rate of progressive massive fibrosis and age, energy expenditure at work, smoking habits, body type, exogenous tuberculous infection, or endogenous infection as measured by the presence of primary complexes in the first radiographs. The only factor related to the attack rate was the average category of simple pneumoconiosis. The attack rate is zero at category $\frac{1}{2}$ and rises to 30 or more per 100 in eight years for category 3. It is argued from this that the logical way to control the appearance of progressive massive fibrosis is to concentrate on preventing miners reaching category 2 of simple pneumoconiosis. Evidence is also presented that considerable progression of simple pneumoconiosis has been occurring during the past eight years amongst coal-face workers at the collieries in this area.

In any discussion on the prevention of progressive massive fibrosis (P.M.F.) the factors influencing its appearance are clearly of the greatest importance. In a previous paper (Cochrane and Miall, 1956) an experiment was described which had been planned to investigate the importance of tuberculous reinfection in the aetiology of P.M.F. At that time the results of a two-and-a-half-year follow-up of miners and ex-miners in two Welsh valleys (Rhondda Fach and Aberdare) were presented, and the various hypotheses about the aetiology of P.M.F. were reviewed. In this paper the results of an eight-year follow-up of parts of the same populations are discussed.

\section{Material and Methods}

The material consisted of an eight-year radiographic follow-up of:

(1) All those miners and ex-miners living in the Rhondda Fach who were radiographed in 1950/51, and whose radiographs were read on either or both occasions in $1950 / 51$ as category 2,3 , or $A$ according to the
International Sydney Classification, 1950 (International Labour Organization, 1953) (population X).

(2) All the miners living in the Aberdare Valley who were radiographed in 1951 and whose radiographs were read on either or both occasions in 1951 as category 1 , 2, 3, or A (population Y).

(3) All the miners at one colliery in the Aberdare Valley who were radiographed in 1951 and whose radiographs were read on either or both occasions in 1951 as category $0,1,2,3$, or $A$ (population $Z$ ). (This population naturally overlaps to some extent with population $Y$.)

The reasons for the use of these apparently odd populations must be briefly stated. It was originally planned to follow up all those, from both valleys, whose radiographs had been read at the time of the first survey as category 2,3 , or A. There was evidence that the attack rate of P.M.F. was higher in those with category 2 or 3 simple pneumoconiosis than in those with category 0 or 1 , so to avoid unnecessary radiation the latter groups were omitted. The follow-up in the Rhondda Fach was completed in 1958, and the material was tabulated at once. The results suggested that the attack rate of P.M.F. was higher in category 3 than in 
TABLE 1

DETAILS OF EXTENT OF FOLLOW-UP IN THE THREE POPULATIONS

\begin{tabular}{|c|c|c|c|c|c|c|c|}
\hline Population & Age Group & No. to be Followed-up & No. Dead & No. Left Area & No. Refused & No. Available & Per cent. Followed-up \\
\hline $\mathbf{x}$ & $\begin{array}{l}25-44 \\
45-64 \\
65+\end{array}$ & $\begin{array}{l}596 \\
506 \\
142\end{array}$ & $\begin{array}{l}13 \\
76 \\
59\end{array}$ & $\begin{array}{r}50 \\
19 \\
7\end{array}$ & $\begin{array}{r}10 \\
6 \\
1\end{array}$ & $\begin{array}{r}523 \\
405 \\
75\end{array}$ & $\begin{array}{l}87 \cdot 8 \\
80 \cdot 0 \\
52 \cdot 8\end{array}$ \\
\hline $\mathbf{Y}$ & $\begin{array}{l}25-44 \\
45-64 \\
65+\end{array}$ & $\begin{array}{r}445 \\
369 \\
23\end{array}$ & $\begin{array}{r}21 \\
52 \\
5\end{array}$ & $\begin{array}{r}12 \\
2 \\
-\end{array}$ & $\begin{array}{r}10 \\
12 \\
2\end{array}$ & $\begin{array}{r}402 \\
303 \\
16\end{array}$ & $\begin{array}{l}90 \cdot 3 \\
82 \cdot 1 \\
69 \cdot 6\end{array}$ \\
\hline $\mathbf{Z}$ & $\begin{array}{l}25-44 \\
45-64 \\
65+\end{array}$ & $\begin{array}{r}313 \\
201 \\
16\end{array}$ & $\begin{array}{r}9 \\
30 \\
7\end{array}$ & $\begin{array}{r}29 \\
6 \\
\end{array}$ & $\begin{array}{l}3 \\
4 \\
1\end{array}$ & $\begin{array}{r}272 \\
161 \\
8\end{array}$ & $\begin{array}{l}86.9 \\
80.5 \\
50.0\end{array}$ \\
\hline
\end{tabular}

category 2, so it was decided to add " another point" to the curve connecting the attack rate with the category of simple pneumoconiosis by including those miners whose radiographs had been read originally as category 1 in the Aberdare Valley. Finally, while working in the Aberdare Valley, only one centre, a colliery first-aid room, was used and to this centre all those to be examined were brought. The management and union lodge of this colliery requested that all the men seen in 1951 who were still employed at the colliery should be re-examined. As it was considered desirable to include some category 0 's in the survey this request was agreed to and thus population $\mathrm{Z}$ was added.

For the purposes of this particular research, the radiographs were categorized by the author using the International Geneva Classification (International Labour Organization, 1959) in two different ways:

(1) The two radiographs of each miner or ex-miner $(1950 / 51$ and 1958 for those in population $X$, and 1951 and 1959 for population $Y$ ) were presented in pairs in chronological order to the reader but with all names, numbers, and dates concealed and with the pairs in a random order (paired readings).

(2) The pairs were separated and the order of the single radiographs randomized. They were then categorized with the identifying features concealed (separate readings).

The radiographs of population $Z$ which did not overlap with population $Y$ were categorized by the same techniques and by the same reader a few months earlier than the others and for this reason have not been used for the main part of the analysis.

Industrial and personal histories were completed at the time of survey and the inter-survey occupations were later classified as "light", " mixed", or " heavy" according to the estimated energy expenditure, without knowledge of the radiographic findings.

\section{Results}

Extent of Follow-up.-The numbers of those who died between the surveys, those who had left the area, and those who refused to co-operate at the time of the second survey are shown in Table 1. The extent of the follow-up seems reasonably satisfactory, and the three populations are very similar.
Methods of Estimating the Attack Rate of P.M.F.With material available from the two methods of categorization, there were several different methods available for tabulating the relationship between the attack rate of P.M.F. and the category of simple pneumoconiosis. For the "attacks" one could use either the "paired" readings, or deduce them from the difference in the number of cases of P.M.F. read using " separate" readings. For the category of simple pneumoconiosis one could use either the category of the first radiograph (chronologically) if one was interested in prognostic studies, or the average category of the first and second radiographs if one was interested in the average amount of pneumoconiotic pathology (or the average amount of dust) in the lungs for the period between the two surveys. $A$ priori, there seemed little reason to exclude any of these possibilities.

The results are given in Table 2 and Figs. 1 and 2. (The justification for neglecting age and for combining populations $\mathrm{X}$ and $\mathrm{Y}$ is given later.) In the figures the categories of simple pneumoconiosis have been roughly spaced to agree with the average dust content of the right lung (Rivers, Wise, King, and Nagelschmidt, 1960). The first and most striking finding is the great variability between readings as all the curves in Fig. 1 should have been similar, as should those in Fig. 2. The reasons for this may be: (i) the marked differences in the quality of the radiographs, and (ii) the unexpected amount of progression of simple pneumoconiosis that apparently occurred. An important point in Table 2 requiring explanation is the difference in the populations at risk. The cause of this is twofold:

(1) Population $\mathrm{X}$ included all radiographs which had on either or both occasions been read as category 2 in 1950/51. This was aimed to include a complete population of 2's and some in the higher ranges of category 1. Population $Y$, by the same argument, contained a complete population of 1's and some in the higher ranges of category 0 . This led to the unfortunate result that the group of 1's 
read in population $\mathrm{X}$ were not comparable with the group of 1's in population $Y$ and could not be added to them. Further, the number of 1's in populations $\mathrm{X}$ and $\mathrm{Y}$ varied according to the method of categorization (separate or paired) so the number of 1's that had to be discarded before joining the two populations varied.

(2) At the other end of the scale, both populations contained the group categorized as A (P.M.F.) in $1950 / 51$ and these had to be excluded to obtain the population at risk of developing P.M.F. The number of A's read by the two methods varied, and so the number of exclusions varied.

The main problem was to decide which method to use for the rest of the analysis. There was little difficulty in deciding that for the particular purpose of aetiology the average category would be more useful than the category of the first radiograph. It also seemed reasonable to discard (1) and (4) in Fig. 1 on the basis of their appearance, leaving (2) and (3) for discussion. Curve (2) in Fig. 1 produces a higher attack rate and would probably be a more sensitive index; but, as a precaution, before a decision was taken, all the radiographs were reviewed in which an "attack of P.M.F." had been read by one method only. The results were illuminating, though somewhat depressing, for the author (and reader) of the radiographs. The " attacks" read with paired radiographs but not on separate radiographs were few in number, and fell into the expected " borderline" group. The others (present when radiographs were read separately but not when the radiographs were read together) were much larger in number, and fell into three groups: a "borderline" group similar to the other, a large group where P.M.F. was certainly present in both radiographs, and a smaller group in which the shadow seen in the second radiograph, when compared with the first radiograph, did not appear to be P.M.F. The first group needs no comment but the second is more interesting. The existence of the P.M.F. shadow in the first radiograph appeared to have been missed for two reasons, i.e. size and radiographic technique. P.M.F. shadows tend to increase with time, and the shadow is therefore easier to see on the second radiograph, and when the situation of the P.M.F. shadow is determined in this way it is easier to recognize the lesion in the first radiograph. If, in addition, the technique of the first radiograph is inferior, much larger lesions can be missed or discounted on the first radiograph. The third group is best described by an example. In one case the first radiograph was of good technique and appeared to show some bronchiectasis in the right mid and lower zones. The second radiograph was a "white" (soft) radiograph in which it was difficult to see the details of the lesion, and when read as a single radiograph it had been called P.M.F. It seemed, on this basis, better to use the readings from the paired radiographs for calculating the attack rate, while using the average of the two separate readings to estimate the category of simple pneumoconiosis (Fig. 1 (3)).

It might appear that too much attention has been

TABLE 2

VARIOUS METHODS OF RELATING ATTACK RATE OF P.M.F. IN EIGHT YEARS TO CATEGORY OF SIMPLE PNEUMOCONIOSIS AMONGST MINERS AND EX-MINERS (AGED 25-64)

(a) Using Both Radiographs to Obtain Average Category of Simple Pneumoconiosis

\begin{tabular}{|c|c|c|c|c|c|c|c|c|c|c|c|c|}
\hline \multirow{3}{*}{$\begin{array}{l}\text { Average } \\
\text { Category }\end{array}$} & \multicolumn{3}{|c|}{$\begin{array}{c}\text { Simple Pneumoconiosis } \\
\text { (Paired)* } \\
\text { Attack Rate (Paired) }\end{array}$} & \multicolumn{3}{|c|}{$\begin{array}{c}\text { Simple Pneumoconiosis } \\
\text { (Separate) } \dagger \\
\text { Attack Rate (Separate) }\end{array}$} & \multicolumn{3}{|c|}{$\begin{array}{c}\text { Simple Pneumoconiosis } \\
\text { (Separate) } \\
\text { Attack Rate (Paired) }\end{array}$} & \multicolumn{3}{|c|}{$\begin{array}{c}\text { Simple Pneumoconiosis } \\
\text { (Paired) } \\
\text { Attack Rate (Separate) }\end{array}$} \\
\hline & \multicolumn{3}{|c|}{1} & \multicolumn{3}{|c|}{2} & \multicolumn{3}{|c|}{3} & \multicolumn{3}{|c|}{4} \\
\hline & No. & Attacks & $\%$ & No. & Attacks & $\%$ & No. & Attacks & $\%$ & No. & Attacks & $\%$ \\
\hline $\begin{array}{l}1 \\
1 \cdot 5 \\
2 \cdot 5 \\
2 \cdot 5 \\
3\end{array}$ & $\begin{array}{r}154 \\
36 \\
557 \\
50 \\
476\end{array}$ & $\begin{array}{r}2 \\
6 \\
77 \\
5 \\
104\end{array}$ & $\begin{array}{r}1.3 \\
16.7 \\
13.8 \\
10.0 \\
21.8\end{array}$ & $\begin{array}{l}124 \\
212 \\
307 \\
292 \\
243\end{array}$ & $\begin{array}{l}\overline{17} \\
63 \\
86 \\
90\end{array}$ & $\begin{array}{r}8.0 \\
20.5 \\
29.5 \\
37.0\end{array}$ & $\begin{array}{l}124 \\
211 \\
313 \\
291 \\
242\end{array}$ & $\begin{array}{l}\overline{15} \\
45 \\
56 \\
72\end{array}$ & $\begin{array}{r}7 \cdot 1 \\
14.4 \\
19 \cdot 2 \\
29.8\end{array}$ & $\begin{array}{r}153 \\
36 \\
568 \\
50 \\
478\end{array}$ & $\begin{array}{r}5 \\
5 \\
125 \\
6 \\
144\end{array}$ & $\begin{array}{r}3.3 \\
13.9 \\
22.0 \\
12.0 \\
30.1\end{array}$ \\
\hline Total & 1,273 & 194 & - & 1,178 & 256 & - & 1,181 & 188 & - & 1,285 & 285 & - \\
\hline
\end{tabular}

(b) Using First Radiograph only to Obtain Category of Simple Pneumoconiosis

\begin{tabular}{|c|c|c|c|c|c|c|c|c|c|c|c|c|}
\hline & \multicolumn{3}{|c|}{5} & \multicolumn{3}{|c|}{6} & \multicolumn{3}{|c|}{7} & \multicolumn{3}{|c|}{8} \\
\hline $\begin{array}{l}1 \\
2 \\
3\end{array}$ & $\begin{array}{l}195 \\
602 \\
476\end{array}$ & $\begin{array}{r}8 \\
82 \\
104\end{array}$ & $\begin{array}{r}5.1 \\
13.6 \\
21.8\end{array}$ & $\begin{array}{l}343 \\
540 \\
295\end{array}$ & $\begin{array}{r}31 \\
120 \\
105\end{array}$ & $\begin{array}{r}9 \cdot 0 \\
22 \cdot 2 \\
35 \cdot 6\end{array}$ & $\begin{array}{l}338 \\
547 \\
296\end{array}$ & $\begin{array}{l}20 \\
84 \\
84\end{array}$ & $\begin{array}{r}6.0 \\
15.4 \\
28.4\end{array}$ & $\begin{array}{l}194 \\
613 \\
478\end{array}$ & $\begin{array}{r}10 \\
131 \\
144\end{array}$ & $\begin{array}{r}5.2 \\
21.4 \\
30 \cdot 1\end{array}$ \\
\hline Total & 1,273 & 194 & - & 1,178 & 256 & - & 1,181 & 188 & - & 1,285 & 285 & - \\
\hline
\end{tabular}

* The two radiographs of each subject read in pairs.

$\dagger$ The two radiographs of each subject read separately. 


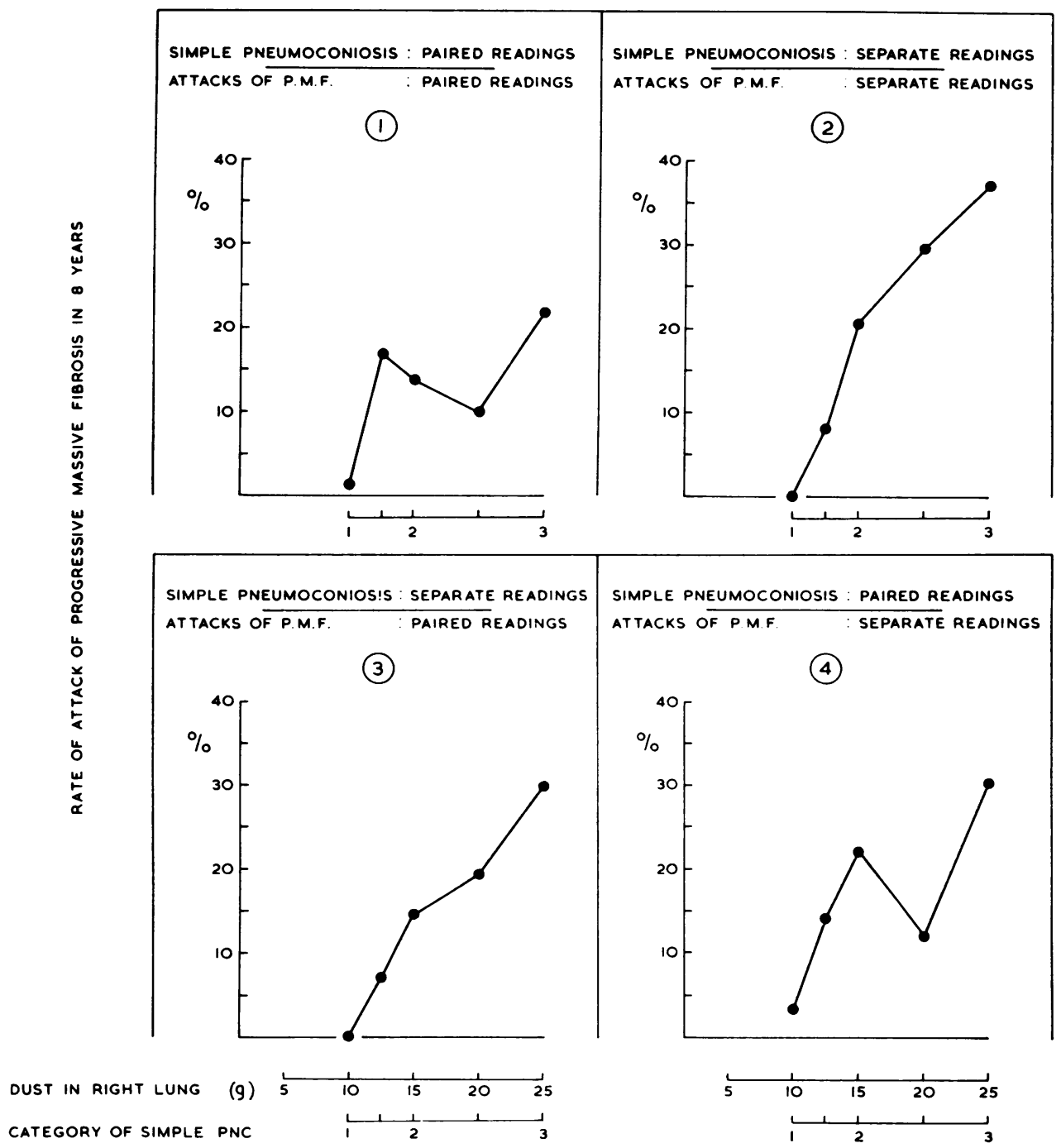

FIG. 1.-Various methods of relating the attack rate of progressive massive fibrosis to the average category of simple pneumoconiosis (miners and ex-miners aged 25-64 in an eight-year follow-up).

devoted to this point. One could argue that either method would do equally well. On the other hand, the actual numerical value of the attack rate of P.M.F. is of importance, as it will probably be the main measure of risk by which the safety of " approved" dust conditions will be judged. It has therefore been thought better to use the method which gave what was believed to be the "truer" figure although it is slightly less sensitive.

Two further small points can be conveniently mentioned here. There is first the problem of the second radiograph where the background of simple pneumoconiosis could not be classified. A choice had to be made between assuming that all were category 3 or that the background was the same as in the first radiograph. The number was small, and the alternative methods gave very similar final results. In the Tables they have been treated as category 3. The other point concerns the method of tabulation shown in Table 3. It assumes that those radiographs with the same average categories, e.g. (1-3, 2-2, and 3-1) are so similar that they may be grouped together. The only test that can be applied is the size of the attack rate in the various 


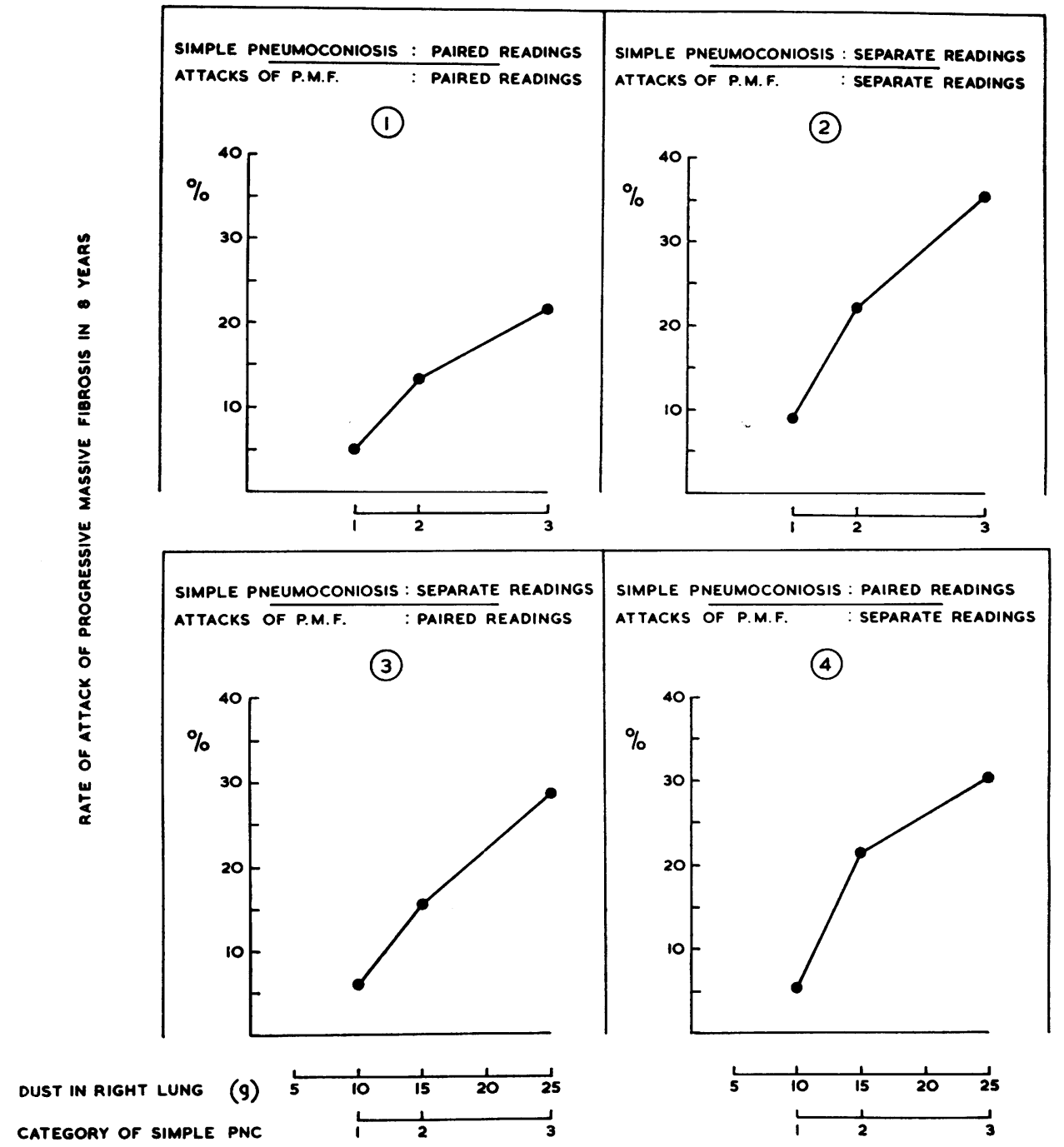

Fig. 2.-Various methods of relating the attack rate of progressive massive fibrosis to the category of simple pneumoconiosis in the first film (miners and ex-miners aged 25-64 in an eight-year follow-up).

sub-groups, and this is shown in the Table and seems satisfactory except for a low value in the " 2-1" sub-group where the number involved is small.

Age.-The relationship between age and the attack rate of P.M.F. is shown in Table 4. The general impression of little effect is rather disturbed by the high attack rates for category 2.5 in the 45-54 and 55-64 age groups, and the somewhat raised rates for category 2 in the 55-64 and 65-74 age groups, but when tested statistically no sig- nificant trend with age was found. This contrasts strongly with the effect of age on the progression of P.M.F. (Cochrane, Moore, and Thomas, 1961). Possible explanations of the scatter in the results, which apparently increases with age, are the increasing difficulty of diagnosing P.M.F. in the presence of other fibrotic lesions and the increased refusal rate in the higher age groups.

Tuberculosis.-The original purpose of surveying these two Welsh valleys was to compare the attack rate of P.M.F. amongst the miners in two mining 
areas, in one of which exogenous tuberculous infectivity had been significantly reduced.

The Rhondda Fach and part of the Aberdare Valley were selected. In both there were four collieries, working the same rank of coal, containing approximately the same number of miners, with similar high certification rates for pneumoconiosis. The economic and social conditions were similar, though it seemed possible that in the Aberdare Valley they were slightly better. This was confirmed by the results of tuberculin testing of schoolchildren in the two valleys (Jarman, 1953).

In order to reduce the tuberculous infectivity in the Rhondda Fach, $90 \%$ of the whole population were radiographed in 1950/51 and 1953 (Cochrane, Cox, and Jarman, 1952, 1955), and it seemed as though the Mantoux positivity rate of schoolchildren was falling faster in the Rhondda Fach than in the Aberdare Valley (Cochrane and Miall, 1956). Since 1953 the Rhondda Fach has been watched very carefully. The sputa of cases of P.M.F. have been repeatedly examined and several small chest radiography surveys have been successfully completed. In spite of this, the process of eradication of tuberculosis has been slow. Fig. 3 shows the number of infectious cases known to the Chest Clinic at the beginning of each year. It shows the more rapid disappearance of infectious tuberculosis from women. It is also interesting to note that P.M.F. originally accounted for only $11.5 \%$ of the male cases but now accounts for 57.0\% illustrating the difficulties introduced by a high prevalence of P.M.F. into the eradication problem.

There are, in addition, two new sources of data comparing the infectivity of the two areas. The first is the notification rates amongst females in the two areas, which are shown in Table 5 and Fig. 4. In the years 1946, 1947, and 1948, the period which had to be used when the valleys were being selected, there was little difference between the notification

TABLE 3

TABLE 5

RELATIONSHIP BETWEEN ATTACK RATE OF P.M.F. AND AVERAGE CATEGORY OF SIMPLE PNEUMOCONIOSIS RADIOGRAPHS READ SEPARATELY IN AGE GROUP 25-64 (TO ILLUSTRATE METHOD OF TABULATION)

\begin{tabular}{|c|c|c|c|c|c|}
\hline \multirow{2}{*}{$\begin{array}{c}\text { Average } \\
\text { Category of } \\
\text { Simple } \\
\text { Pneumoconiosis }\end{array}$} & \multicolumn{2}{|c|}{\begin{tabular}{c|} 
Category of \\
Radiograph Dated
\end{tabular}} & \multirow[t]{2}{*}{ No. } & \multirow{2}{*}{$\begin{array}{c}\text { No. } \\
\text { Attacked }\end{array}$} & \multirow[t]{2}{*}{ Per cent. } \\
\hline & $1950 / 51$ & $1958 / 59$ & & & \\
\hline 1.0 & 1 & 1 & 124 & 0 & 0.0 \\
\hline \multirow[t]{2}{*}{1.5} & $\begin{array}{l}1 \\
2\end{array}$ & $\begin{array}{l}2 \\
1\end{array}$ & $\begin{array}{r}174 \\
37\end{array}$ & $\begin{array}{r}14 \\
1\end{array}$ & $\begin{array}{l}8 \cdot 0 \\
2 \cdot 8\end{array}$ \\
\hline & \multicolumn{2}{|c|}{ Total } & 211 & 15 & $7 \cdot 1$ \\
\hline \multirow[t]{2}{*}{$2 \cdot 0$} & $\begin{array}{l}1 \\
2 \\
3\end{array}$ & $\begin{array}{l}3 \\
2 \\
1\end{array}$ & $\begin{array}{r}40 \\
271 \\
2\end{array}$ & $\begin{array}{r}6 \\
39 \\
0\end{array}$ & $\begin{array}{r}15.0 \\
14.4 \\
0.0\end{array}$ \\
\hline & \multicolumn{2}{|c|}{ Total } & 313 & 45 & $14 \cdot 4$ \\
\hline \multirow[t]{2}{*}{$2 \cdot 5$} & 2 & $\begin{array}{l}3 \\
2\end{array}$ & $\begin{array}{r}239 \\
52\end{array}$ & $\begin{array}{l}44 \\
12\end{array}$ & $\begin{array}{l}18 \cdot 4 \\
23 \cdot 1\end{array}$ \\
\hline & \multicolumn{2}{|c|}{ Total } & 291 & 56 & $19 \cdot 2$ \\
\hline 3.0 & 3 & 3 & 242 & 72 & 29.8 \\
\hline Total & & & 1,181 & 188 & \\
\hline
\end{tabular}

NOTIFICATION RATES FOR PULMONARY TƯBERCULOSIS AMONGST FEMALES (PER 10,000) IN THE RHONDDA FACH AND ABERDARE VALLEY

\begin{tabular}{|c|c|c|}
\hline \multirow[b]{2}{*}{ Year } & \multicolumn{2}{|c|}{ Notification Rates } \\
\hline & Rhondda Fach & Aberdare Valley \\
\hline $\begin{array}{l}1946 \\
1947 \\
1948 \\
1949 \\
1950 \\
1951 \\
1952 \\
1953 \\
1954 \\
1955 \\
1956 \\
1957 \\
1958 \\
1959\end{array}$ & $\begin{array}{r}14 \cdot 3(19) \\
15.8(21) \\
13.5(18) \\
24.0(32) \\
* 34.5(46) \\
* 24.0(32) \\
12.8(17) \\
* 19.5(26) \\
10.5(14) \\
+12.0(16) \\
5.3(7) \\
5.3(7) \\
+1.5(2) \\
3.0(4)\end{array}$ & $\begin{array}{r}14.4(53) \\
13.1(48) \\
15.5(57) \\
12.0(44) \\
11.7(43) \\
+10.1(37) \\
12.5(46) \\
23.7(87) \\
+14.2(52) \\
7.6(28) \\
6.3(23) \\
6.0(22) \\
6.0(22) \\
+4.6(17)\end{array}$ \\
\hline
\end{tabular}

* Major $x$-ray survey.

$\dagger$ Minor $x$-ray survey.

Number of cases are given in parenthesis.

TABLE 4

ATTACK RATE OF P.M.F. AMONGST MINERS AND EX-MINERS (AGED 25-69) IN EIGHT YEARS, BY AVERAGE CATEGORY OF SIMPLE PNEUMOCONIOSIS AND AGE

\begin{tabular}{|c|c|c|c|c|c|c|c|c|c|c|c|c|c|c|c|}
\hline \multirow{3}{*}{$\begin{array}{l}\text { Average } \\
\text { Category }\end{array}$} & \multicolumn{15}{|c|}{ Age Groups } \\
\hline & \multicolumn{3}{|c|}{$25-34$} & \multicolumn{3}{|c|}{$35-44$} & \multicolumn{3}{|c|}{$45-54$} & \multicolumn{3}{|c|}{$55-64$} & \multicolumn{3}{|c|}{$65-69$} \\
\hline & No. & Attacks & $\%$ & No. & Attacks & $\%$ & No. & Attacks & $\%$ & No. & Attacks & $\%$ & No. & Attacks & $\%$ \\
\hline $\begin{array}{l}1 \\
1.5 \\
2 \\
2.5 \\
3\end{array}$ & $\begin{array}{l}11 \\
47 \\
68 \\
80 \\
57\end{array}$ & $\begin{array}{r}-2 \\
9 \\
12 \\
18\end{array}$ & $\begin{array}{r}\overline{4.3} \\
13.2 \\
15.0 \\
31.6\end{array}$ & $\begin{array}{r}47 \\
81 \\
121 \\
114 \\
100\end{array}$ & $\begin{array}{r}-8 \\
18 \\
16 \\
31\end{array}$ & $\begin{array}{r}\overline{9.9} \\
14.9 \\
14.0 \\
31.0\end{array}$ & $\begin{array}{l}39 \\
61 \\
76 \\
72 \\
64\end{array}$ & $\begin{array}{r}-4 \\
9 \\
17 \\
20\end{array}$ & $\begin{array}{r}\overline{6.6} \\
11.8 \\
23.6 \\
31.3\end{array}$ & $\begin{array}{l}27 \\
22 \\
48 \\
25 \\
21\end{array}$ & $\begin{array}{r}1 \\
9 \\
11 \\
3\end{array}$ & $\begin{array}{r}\overline{4 \cdot 5} \\
18 \cdot 8 \\
44 \cdot 0 \\
14 \cdot 3\end{array}$ & $\begin{array}{r}2 \\
7 \\
18 \\
10 \\
5\end{array}$ & $\begin{array}{l}\overline{1} \\
4 \\
1 \\
1\end{array}$ & $\begin{array}{l}\overrightarrow{14 \cdot 3} \\
22 \cdot 2 \\
10 \cdot 0 \\
20 \cdot 0\end{array}$ \\
\hline
\end{tabular}




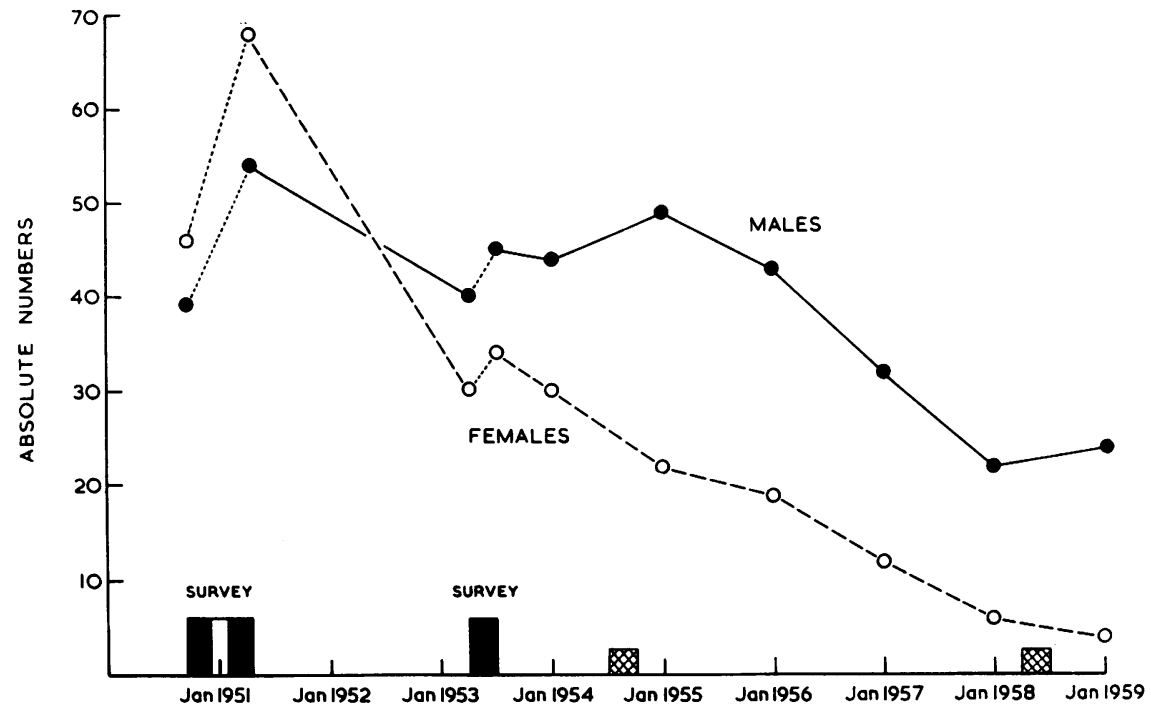

Fig. 3.-The numbers of known infectious cases of pulmonary tuberculosis in the Rhondda Fach at home or in hospital before the $1950 / 51$ survey and at various times since.

rates in the two valleys, but in 1949 (before the survey started) there was a dramatic rise in notification rates in the Rhondda Fach although the actual number involved was relatively small. This rise may have been associated with the appointment of a new chest physician or with an epidemic of tuberculosis, but in either case there is some doubt about the two populations being originally as comparable as was thought. This is supported by the fact that the prevalence of Mantoux positivity was originally higher in the Rhondda Fach (Cochrane et al., 1955). The other source of evidence is the result of routine Mantoux testing of schoolchildren before B.C.G. is given. Unfortunately B.C.G. administration is not done by the same local authority in the two valleys but the techniques used are similar. Both valleys had $15 \%$ of children positive at the age of 13 in 1958 and

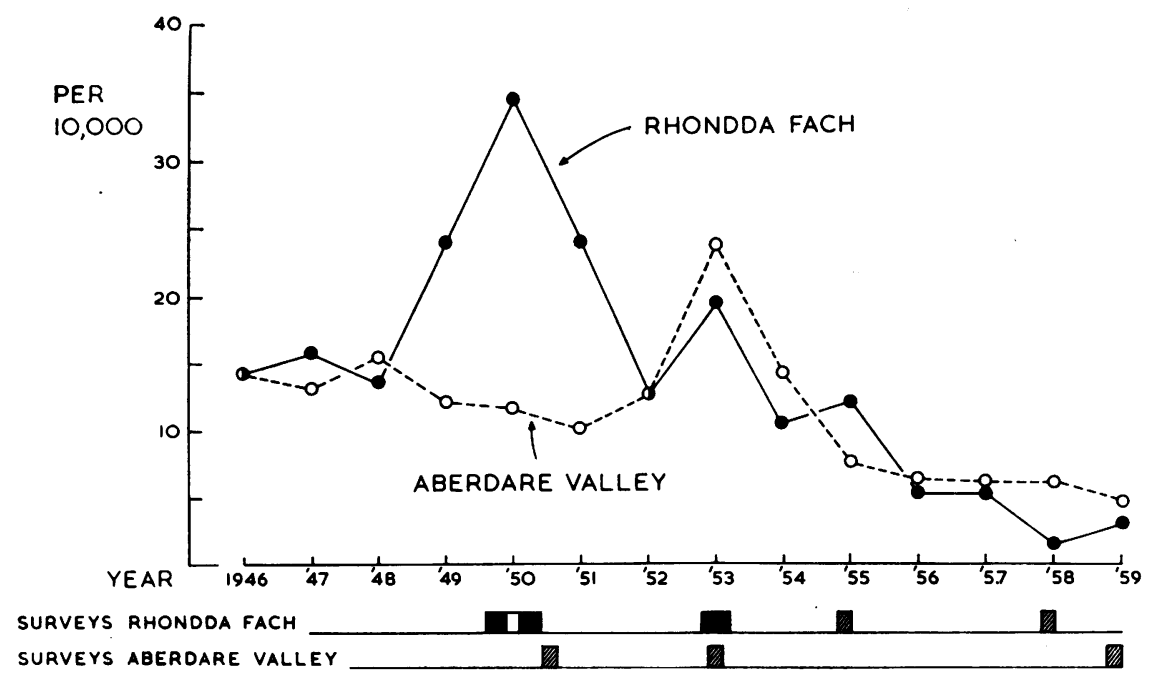

FIG. 4.-Notification rates for pulmonary tuberculosis amongst females in two South Wales mining valleys (1946-1959). 
TABLE 6

ATTACK RATE OF P.M.F. AMONGST MINERS, AGED 25-64, IN THE TWO VALLEYS IN EIGHT YEARS BY AVERAGE CATEGORY OF SIMPLE PNEUMOCONIOSIS

\begin{tabular}{|c|c|c|c|c|c|c|}
\hline \multirow{2}{*}{$\begin{array}{l}\text { Average } \\
\text { Category }\end{array}$} & \multicolumn{3}{|c|}{ Miners (Population X) } & \multicolumn{3}{|c|}{ Miners (Population Y) } \\
\hline & No. & Attacks & $\%$ & No. & Attacks & $\%$ \\
\hline $\begin{array}{l}2 \\
2 \cdot 5\end{array}$ & $\begin{array}{r}103 \\
119 \\
77\end{array}$ & $\begin{array}{l}19 \\
22 \\
23\end{array}$ & $\begin{array}{l}18.4 \\
18.5 \\
29.9\end{array}$ & $\begin{array}{r}92 \\
101 \\
83\end{array}$ & $\begin{array}{l}11 \\
19 \\
29\end{array}$ & $\begin{array}{l}11.9 \\
18.8 \\
34.9\end{array}$ \\
\hline Total & 299 & 64 & - & 276 & 59 & - \\
\hline
\end{tabular}

1959, and it seems probable, therefore, that in spite of the originally promising evidence there is no real difference in infectivity between the two valleys now. This may be due either to the fact that there was originally much more tuberculosis in the Rhondda Fach than in the Aberdare Valley, or that there is a higher prevalence of P.M.F. in the Rhondda Fach, which has made eradication of pulmonary tuberculosis more difficult, but the prevalence of P.M.F. amongst miners and ex-miners in the Aberdare Valley is not known. There is clearly no difference in the attack rate of P.M.F. (Table 6) between the two valleys.

It was impossible to test the "tuberculosis" hypothesis as had originally been planned, but it did seem possible to test the hypothesis in another way, i.e. by a secondary investigation. The evidence both from Mantoux testing and from notification rates suggested a continuous fall in tuberculous infectivity from 1950 to 1959 and it seemed reasonable to assume that the infectivity was higher in the first period (1950-1953) than in the second (1953-1959). Thus, if the attack rate of P.M.F. could be measured in the two periods the hypothesis could be tested. This was attempted using only those radiographs which were read as category 3 in 1950/51 and 1959 , in order to have maximal sensitivity. Paired readings were used with the identifying features of the radiographs concealed, the pairs of radiographs being presented in a random order. The annual attack rate of P.M.F. for the two periods was $4.1 \%$ and $4 \cdot 3 \%$. This compares reasonably well with the
TABLE 7

ATTACK RATE OF P.M.F. AMONGST MINERS AND EXMINERS, AGED 25-64, IN EIGHT YEARS, ACCORDING TO PRESENCE OR ABSENCE OF A CALCIFIED PRIMARY PRESENCE OR ABSENCE OF A CALCIFIED PRIN
COMPLEX IN THE FIRST RADIOGRAPH

\begin{tabular}{|c|c|c|c|c|c|c|}
\hline \multirow{2}{*}{$\begin{array}{l}\text { Average } \\
\text { Category }\end{array}$} & \multicolumn{3}{|c|}{$\begin{array}{c}\text { With Calcified Primary } \\
\text { Complex }\end{array}$} & \multicolumn{3}{|c|}{$\begin{array}{c}\text { Without Calcified Primary } \\
\text { Complex }\end{array}$} \\
\hline & No. & Attacks & $\%$ & No. & Attacks & $\%$ \\
\hline $\begin{array}{l}1 \\
1 \cdot 5 \\
2 \\
2 \cdot 5 \\
3\end{array}$ & $\begin{array}{l}30 \\
59 \\
77 \\
68 \\
74\end{array}$ & $\begin{array}{r} \\
4 \\
14 \\
13 \\
22\end{array}$ & $\begin{array}{r}\overline{6} .8 \\
18.2 \\
19.1 \\
29.8\end{array}$ & $\begin{array}{r}94 \\
152 \\
236 \\
223 \\
168\end{array}$ & $\begin{array}{l}\overline{11} \\
31 \\
43 \\
50\end{array}$ & $\begin{array}{c}\overline{7} \cdot 2 \\
13 \cdot 1 \\
19 \cdot 3 \\
29.8\end{array}$ \\
\hline
\end{tabular}

figures for the whole period- $3.7 \%$ (Table 2) and does not suggest that there had been any reduction in the attack rate as the infectivity fell.

As regards endogenous as opposed to exogenous infection, the presence of healed primary-type tuberculosis can be used as the index, based on the first radiographs of the single radiograph readings. The results are shown in Table 7 . There was no significant difference between the two groups but this does not mean that endogenous tuberculous infection is not important. It means that no supporting evidence from this rather limited point of view has been found.

Occupation Between Surveys.-For this analysis, the material from populations $\mathrm{X}$ and $\mathrm{Y}$ has been combined. The industrial histories were coded according to the heaviness of the work done. The comparison between the effects of light and heavy work is shown in Table 8 where it can be seen that there is no suggestion of any difference in the attack rate of P.M.F.

\section{Personal Characteristics}

(i) Smoking Habits.-To investigate this the population has been sub-divided into smokers, non-smokers, and ex-smokers, and the results of the analysis are shown in Table 9 where again it can be seen that there are no significant differences.

(ii) Body Type.-In a previous paper (Cochrane and Miall, 1956) suggestive evidence was found that those attacked by P.M.F. had a higher body

TABLE 8

ATTACK RATE OF P.M.F. AMONGST MINERS AND EX-MINERS, AGED 25-64, IN EIGHT YEARS, BY AVERAGE CATEGORY OF SIMPLE PNEUMOCONIOSIS AND TYPE OF OCCUPATION

\begin{tabular}{|c|c|c|c|c|c|c|c|c|c|c|c|c|}
\hline \multirow{3}{*}{$\begin{array}{l}\text { Average } \\
\text { Category }\end{array}$} & \multicolumn{12}{|c|}{ Type of Occupation } \\
\hline & \multicolumn{3}{|c|}{ "Light" } & \multicolumn{3}{|c|}{ "Mixed" } & \multicolumn{3}{|c|}{ "Heavy", } & \multicolumn{3}{|c|}{ " Light" and " Mixed" } \\
\hline & No. & Attacks & $\%$ & No. & Attacks & $\%$ & No. & Attacks & $\%$ & No. & Attacks & $\%$ \\
\hline $\begin{array}{l}1 \\
1 \cdot 5 \\
2 \\
2 \cdot 5 \\
3\end{array}$ & $\begin{array}{l}22 \\
35 \\
62 \\
54 \\
60\end{array}$ & $\begin{array}{r}\overline{2} \\
9 \\
14 \\
14\end{array}$ & $\begin{array}{r}\overline{5 \cdot 7} \\
14 \cdot 5 \\
25 \cdot 9 \\
23 \cdot 3\end{array}$ & $\begin{array}{l}18 \\
24 \\
43 \\
25 \\
23\end{array}$ & $\begin{array}{l}-3 \\
7 \\
7 \\
8\end{array}$ & $\begin{array}{l}\overline{12.5} \\
17.4 \\
28.0 \\
34.8\end{array}$ & $\begin{array}{r}84 \\
152 \\
208 \\
212 \\
159\end{array}$ & $\begin{array}{l}\overline{10} \\
29 \\
35 \\
50\end{array}$ & $\begin{array}{r}\overline{6.6} \\
13.9 \\
16.5 \\
31.4\end{array}$ & $\begin{array}{r}40 \\
59 \\
105 \\
79 \\
83\end{array}$ & $\begin{array}{r}\overline{5} \\
16 \\
21 \\
22\end{array}$ & $\begin{array}{r}\overline{8} \cdot 5 \\
15 \cdot 2 \\
26 \cdot 6 \\
26 \cdot 5\end{array}$ \\
\hline
\end{tabular}


TABLE 9

ATTACK RATE OF P.M.F. AMONGST MINERS AND EX-MINERS, AGED 25-64, IN EIGHT YEARS, BY AVERAGE CATEGORY OF SIMPLE PNEUMOCONIOSIS AND SMOKING HABITS

\begin{tabular}{|c|c|c|c|c|c|c|c|c|c|c|c|c|}
\hline \multirow{3}{*}{$\begin{array}{l}\text { Average } \\
\text { Category }\end{array}$} & \multicolumn{12}{|c|}{ Type of Smoker } \\
\hline & \multicolumn{3}{|c|}{ Non-smokers } & \multicolumn{3}{|c|}{ Ex-smokers } & \multicolumn{3}{|c|}{ Smokers } & \multicolumn{3}{|c|}{ Non- and Ex-smokers } \\
\hline & No. & Attacks & $\%$ & No. & Attacks & $\%$ & No. & Attacks & $\%$ & No. & Attacks & $\%$ \\
\hline $\begin{array}{l}1 \\
1 \cdot 5 \\
2 \\
2 \cdot 5 \\
3\end{array}$ & $\begin{array}{r}9 \\
20 \\
29 \\
35 \\
39\end{array}$ & $\begin{array}{r}-3 \\
4 \\
5 \\
12\end{array}$ & $\begin{array}{l}\overline{15.0} \\
13.8 \\
14.3 \\
30.8\end{array}$ & $\begin{array}{l}11 \\
17 \\
34 \\
29 \\
24\end{array}$ & $\begin{array}{l}-1 \\
6 \\
7 \\
7\end{array}$ & $\begin{array}{r}\overline{5 \cdot 9} \\
17 \cdot 6 \\
24 \cdot 1 \\
29 \cdot 2\end{array}$ & $\begin{array}{l}104 \\
174 \\
250 \\
227 \\
179\end{array}$ & $\begin{array}{l}\overline{11} \\
35 \\
44 \\
53\end{array}$ & $\begin{array}{r}\overline{6} \cdot 3 \\
14 \cdot 0 \\
19 \cdot 4 \\
29 \cdot 6\end{array}$ & $\begin{array}{l}20 \\
37 \\
63 \\
64 \\
63\end{array}$ & $\begin{array}{r}-4 \\
10 \\
12 \\
19\end{array}$ & $\begin{array}{l}\overline{10.8} \\
15.9 \\
18 \cdot 8 \\
30.2\end{array}$ \\
\hline
\end{tabular}

index (Rees and Eysenck, 1945) than those not so attacked. The difference, however, did not reach the conventional level of significance. The point was reinvestigated with these new data and no evidence of any difference was found.

Shape of Attack Rate Curve.-In this section the data from all three populations, $X, Y$, and $Z$ (excluding the overlaps) have been combined to give a more complete picture of the attack rate of P.M.F. in relation to the average category of simple pneumoconiosis. The results for the two favoured methods of tabulation are shown in Fig. 5 and Table 10. They are of interest from several points of view. In the first place they demonstrate clearly a very marked rise in attack rate from nil at category 0.5 to $30 \%$ or more at category 3 . The attacks read in association with category 0 were diagnosed and treated as tuberculous, but radio-
TABLE 10

ATTACK RATE OF P.M.F.* AMONGST MINERS AND EX-MINERS, AGED 25-64, IN EIGHT YEARS IN ALL THREE POPULATIONS

\begin{tabular}{|c|c|c|c|c|c|c|}
\hline \multirow[t]{2}{*}{$\begin{array}{l}\text { Average } \\
\text { Category }\end{array}$} & \multicolumn{3}{|c|}{$\begin{array}{c}\text { Simple Pneumoconiosis } \\
\text { (Separate) } \\
\text { Attack Rate (Paired) }\end{array}$} & \multicolumn{3}{|c|}{$\begin{array}{c}\text { Simple Pneumoconiosis } \\
\text { (Separate) } \\
\text { Attack Rate (Separate) }\end{array}$} \\
\hline & No. & Attacks & $\%$ & No. & Attacks & $\%$ \\
\hline $\begin{array}{l}0 \\
0.5 \\
1 \\
1 \cdot 5 \\
2 \cdot 5 \\
2 \cdot 5 \\
3\end{array}$ & $\begin{array}{r}107 \\
64 \\
171 \\
235 \\
317 \\
293 \\
242\end{array}$ & $\begin{array}{c}2 \\
1 \\
16 \\
45 \\
56 \\
72\end{array}$ & $\begin{array}{r}1.9 \\
0.6 \\
6.8 \\
14.2 \\
19.1 \\
29.8\end{array}$ & $\begin{array}{r}107 \\
64 \\
171 \\
236 \\
311 \\
294 \\
243\end{array}$ & $\begin{array}{r}2 \\
2 \\
18 \\
63 \\
86 \\
90\end{array}$ & $\begin{array}{r}1.9 \\
1.2 \\
7.6 \\
20.3 \\
29.3 \\
37.0\end{array}$ \\
\hline
\end{tabular}

* Including two " attacks" of pulmonary tuberculosis.

logically they cannot be distinguished from P.M.F. apart from the background of simple pneumoconiosis.

The values for the attack rate associated with category 0 , category $0 \cdot 5$, and category 1 are not, of course, significantly different but the trend is of

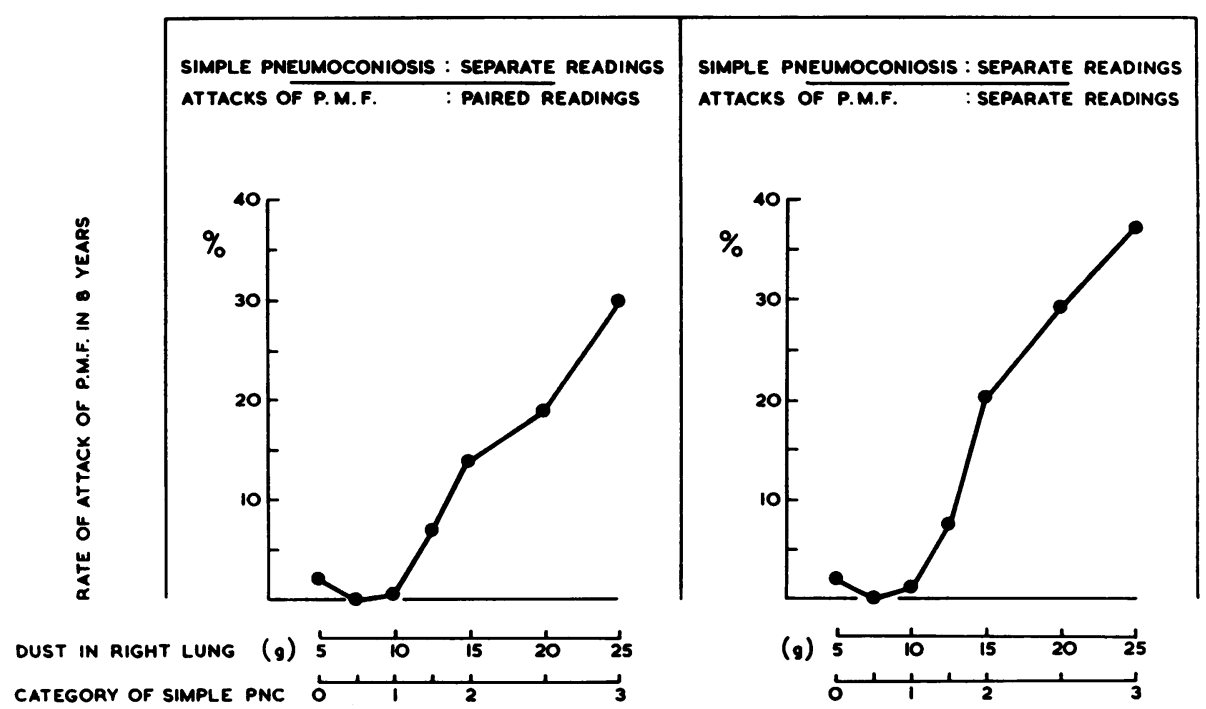

FIG. 5.-Attack rate of progressive massive fibrosis (including two attacks of pulmonary tuberculosis) amongst miners and ex-miners aged 25-64 in eight years by average category of simple pneumoconiosis. 
interest. In a previous paper (Cochrane, 1954), after reviewing the literature and work of the Pneumoconiosis Research Unit, the present author concluded that there was something in the old adage " a little dust is good for you ", suggesting that a small dose of coal dust might have some protective value against tuberculosis; the minimal value of the attack rate curve at category 0.5 would certainly be compatible with this idea, but it cannot, of course, be claimed as definite evidence in its support. The trend would also be compatible with the idea that dust exposure was good for tuberculosis and that P.M.F. was quite a separate condition, not related to tuberculous infection.

The curves are also of interest in the light they throw on objectives in preventive medicine. In both curves there is a very sharp rise between category 1 and category 2 in the attack rate, and it seems clear that the aim should be to prevent progression past category 1 if the appearance of P.M.F. is to be controlled.

\section{Discussion}

Aetiology of Progressive Massive Fibrosis.-In a previous publication (Cochrane and Miall, 1956) the various theories about the aetiology of P.M.F. were reviewed, and it was concluded then, on the basis of pathological, bacteriological, radiological, chemical, and epidemiological evidence, that the tuberculosis hypothesis was the most probable. Since that time there have been a few publications relevant to this which are best discussed in relation to the various hypotheses.

(1) The " silica" hypothesis has in general lost ground through the publication of several new cases of progressive massive fibrosis in which free silica has not been found when the lung has been analysed chemically, or only in very low amounts which did not exceed those found in normal lungs (Watson, Black, Doig, and Nagelschmidt, 1959; Vaccarezza, 1958). In addition, D. Rivers (personal communication, 1960) has found no increased concentration of silica in the isolated P.M.F. lesion compared with the simple pneumoconiosis elsewhere in the lung. On the other hand, the silica hypothesis has probably been discussed more often recently than in the past because of the interest aroused by the Milan School's hypothesis about the aetiology of the silicotic nodule (Vigliani and Pernis, 1958).

This theory, in brief, suggests that the macrophages, dying after the ingestion of silica particles, produce a substance or substances which stimulate the local production of collagen, and also stimulate the reticulo-endothelial system so that there is an increased antibody response to any antigen present. They suggested that this might play a role in the aetiology of P.M.F. but at present there is no direct evidence of its importance, apart from the fact that the gammaglobulin is slightly raised in cases of P.M.F. (Cochrane, Davies, Chapman, and Rae, 1956); however, this would be as compatible with the "infective" hypothesis as with the silica one.

(2) No new evidence has been published in support of the "other infections" hypothesis, and the evidence against it has been ably marshalled by Gough (1959). The evidence in the section on smoking habits in the present paper, and the unimportance of smoking could also be cited here.

(3) The "total dust" hypothesis has also been weakened by the discovery that many lungs with simple pneumoconiosis without progressive massive fibrosis have as much dust in them as cases with P.M.F. (King, Maguire, and Nagelschmidt, 1956; Rivers et al., 1960). However, the evidence in Fig. 5 of the present paper could now be cited in favour of this hypothesis.

(4) The "tuberculosis" hypothesis has been strongly reinforced by the animal work done at Hammersmith by Professor King and his colleagues (Zaidi, Harrison, King, and Mitchison, 1955; King, Harrison, Mohanty, and Mitchison, 1953; King, Yoganathan, Harrison, and Mitchison, 1957; Attygalle, Harrison, King, and Mohanty, 1954), and in America by Gross (Gross, Westrick, and McNerney, 1957). Both groups have shown that collagenous lesions resembling P.M.F. can be produced in animals with a mixture of coal dust and acid-fast bacilli of low virulence. It is of interest that King and his co-workers have observed that there appears to be some relationship between the amount of dust in the lungs and the success of the experiment.

The present position is that the "silica" hypothesis has lost and the "tuberculosis" hypothesis has gained ground, but that no support for the latter has been found epidemiologically.

Prevention of Progressive Massive Fibrosis.Action at any particular time can only be based on the best knowledge available. In earlier years it appeared reasonable to hope that a rapid reduction in exogenous tuberculous infection might result in a reduction in the risk of developing P.M.F. This would have removed the greatest source of disability and excess mortality without making the engineers' task of dust control too difficult. This no longer seems a reasonable hope in the area we studied. Unsatisfactory though the Two Valley Experiment has been in some ways, there is no doubt that after a major anti-tuberculosis campaign the rate of appearance of new cases of P.M.F. is still far too high. In addition, a very close quantitative 
relationship between the category of simple pneumoconiosis and the risk of developing P.M.F. has been found. It seems therefore logical to turn to the control of the category of simple pneumoconiosis as the best means of controlling P.M.F. It is impossible, at present, to reduce the category of simple pneumoconiosis or alter the risk of attack associated with the present categories of miners. One must, therefore, concentrate on preventing any increase in category, i.e. the progression of simple pneumoconiosis to a category higher than 1 , and this, as far as present knowledge goes, can only be done by control of the dust concentrations and the length of time miners are exposed to them.

The progression of simple pneumoconiosis has been less studied than that of progressive massive fibrosis. In the first place, P.M.F. is a more serious condition, and secondly the National Coal Board's large-scale Pneumoconiosis Field Research Scheme, which has now been in progress for more than five years, is relied upon to give all the answers about simple pneumoconiosis that are required. No report has yet been made, but some information about the progression of simple pneumoconiosis in the area in which the work reported here was done has emerged from the work of the Pneumoconiosis Research Unit. For instance, during the 1950/51$1953 / 54$ follow-up of the miners in the eight collieries in the Rhondda Fach and the Aberdare Valley a study was made of the change of category of simple pneumoconiosis of men on the coal-face during the period between the two surveys. There is still considerable doubt as to the best method of assessing change of category as the readings tend to be biased by the technical quality of the radiographs and preconceptions about progression on the part of the observers. It was, therefore, thought better on this occasion to conceal all identifying features such as name and date and to categorize the radiographs separately. This was done by Dr. W. E. Miall and the author, and the results are shown in Table 11. It is clear that there was a significant trend towards the higher category at the time of the second survey. This, however, could have been due to differences in radiographic technique, which certainly existed. One way round this difficulty was to assess the radiographs for technique separately, and then repeat the tabulation using only the radiographs of acceptable technique. This was done and the same trend was found, but the radiographs of acceptable technique did not represent a random sample of the population.

Another example of such progression can be seen in a further study of some of the coal-face workers in population $\mathbf{Z}$-the " pure" colliers. As previously, the first and second radiographs were
TABLE 11

COMPARISON OF CATEGORIES OF SIMPLE PNEUMOCONIOSIS IN 687 RADIOGRAPHS OF COAL-FACE WORKERS AT EIGHT WELSH COLLIERIES EXAMINED ON TWO OCCASIONS TWO AND A HALF YEARS APART (1950/5153 AND 1951-54). RADIOGRAPHS READ SEPARATELY

\begin{tabular}{|c|c|c|c|c|c|}
\hline \multirow{2}{*}{$\begin{array}{c}\text { Category of } \\
\text { Simple } \\
\text { Pneumoconiosis } \\
\text { First Occasion }\end{array}$} & \multicolumn{4}{|c|}{$\begin{array}{c}\text { Category of Simple Pneumoconiosis } \\
\text { Second Occasion }\end{array}$} & \multirow[t]{2}{*}{ Total } \\
\hline & 0 & 1 & 2 & 3 & \\
\hline 0 & 327 & 85 & 42 & - & 454 \\
\hline 1 & 6 & 35 & 37 & 11 & 89 \\
\hline 2 & 3 & 4 & 47 & 30 & 84 \\
\hline 3 & - & 1 & 5 & $-\frac{2}{54}$ & 60 \\
\hline Total & 336 & 125 & 131 & 95 & 687 \\
\hline
\end{tabular}

In 19 radiographs category was lower on second occasion.

In 205 radiographs category was higher on second occasion.

randomized and the identifying features concealed. In addition, they were mixed with a matched sample of radiographs of men from the same colliery who had either not been exposed to dust during the period between the two surveys or had had only a minimal dust exposure, i.e. surface workers. These radiographs were read by several readers, including Dr. P. J. Chapman (at that time one of the National Coal Board's readers in the Field Research Scheme), and his readings are shown in Table 12. It is clear from this Table that very considerable progression of simple pneumoconiosis has taken place among coal-face workers in population $Z$. The fact that Dr. Chapman found no progression amongst those men exposed to little or no dust, while reading their radiographs at the same time as the others, being unaware of the industrial histories, makes these results even more significant than the others.

Evidence based on "certifications" is never completely satisfactory, but the figures in Table 13 suggest that the chance of developing pneumoconiosis amongst young miners is very much greater in the South Western Division than in the others, and that within the South Western Division the worst areas are Rhondda and Aberdare-approximately the two areas where the Pneumoconiosis Research Unit has been working.

It is logical at this stage to turn to the dust conditions in these collieries over this period. The work of the National Coal Board in this connexion has been described by Fay and Tomlinson (1959). Briefly, the basis for approved conditions is a " gentleman's agreement" between the N.C.B. and other interested parties to consider as " approved" those areas of a mine where concentrations less than " 850 particles per $\mathrm{ml}$." are found in the size range $1-5 \mu$ ("650 particles per ml." for anthracite mines). These figures were reached on the basis of the best evidence then available and have always been considered provisional. The N.C.B.'s Field Research 
TABLE 12

COMPARISON OF CATEGORIES OF SIMPLE PNEUMOCONIOSIS (ON TWO OCCASIONS EIGHT YEARS APART) USING RADIOGRAPHS OF "PURE" COLLIERS AND A MATCHED SAMPLE OF THOSE WITH MINIMAL DUST EXPOSURE

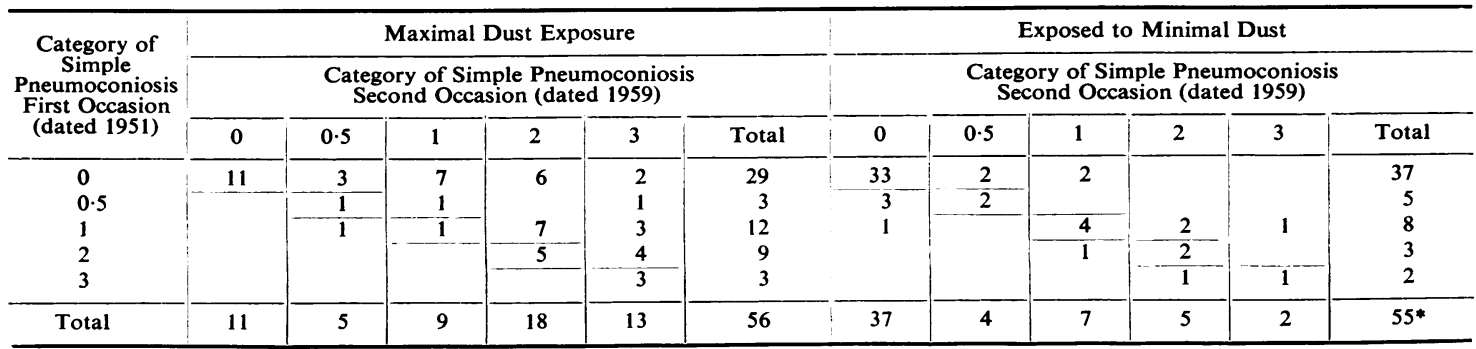

In one radiograph category was lower on second occasion; in 34 radiographs category was higher on second occasion.
In six radiographs category was lower on second occasion; in seven radiographs category was higher on second occasion.

* Plus one technically unreadable by this reader.

Radiographs read separately by Dr. P. J. Chapman (for this work a category 0.5 was introduced to increase the sensitivity of the readings).

TABLE $13 *$

NEW CERTIFICATIONS FOR PNEUMOCONIOSIS AMONGST YOUNG MINERS 1951-1957

(a) By N.C.B. Divisions

\begin{tabular}{l|c}
\hline \multicolumn{1}{c|}{ Divisions } & $\begin{array}{r}\text { Certifications per 1,000 Underground Workers } \\
\text { Aged } 40 \text { and Under }\end{array}$ \\
\hline Scottish & $0 \cdot 5$ \\
Northern & $0 \cdot 6$ \\
Durham & $2 \cdot 8$ \\
N. Eastern & $1 \cdot 2$ \\
N. Western & $4 \cdot 7$ \\
E. Midlands & $0 \cdot 2$ \\
W. Midlands & $8 \cdot 3$ \\
S. Western & $20 \cdot 4$ \\
S. Eastern & $8 \cdot 3$ \\
& \\
\hline
\end{tabular}

(b) BY AREA in S. WALES

\begin{tabular}{l|c|c}
\hline Area in & \multicolumn{2}{|c}{ Certifications per 1,000 Underground Workers } \\
\cline { 2 - 3 } S. Wales & Aged 30 and Under & Aged 40 and Under \\
\hline Swansea & $1 \cdot 3$ & 15.9 \\
Maesteg & 3.5 & 24.9 \\
Rhondda & 6.1 & 31.4 \\
Aberdare & 5.7 & $31 \cdot 1$ \\
Rhymney & 2.9 & $21 \cdot 3$ \\
Monmouth & 0.6 & $9 \cdot 1$ \\
\hline
\end{tabular}

* I am indebted to Dr. Andrew Meiklejohn for this Table.

Scheme is designed to test out their validity, but no definite results are yet available. South Wales pioneered dust suppression, and for many years only a very small proportion of their " coal-faces" have been returned as " unapproved". In practice any dust count which comes above the defined limit leads at once to investigation and action, so that no "coal-face" should remain "unapproved" for any length of time. The introduction of the system of " approved" conditions has undoubtedly made a great improvement in Welsh collieries.
In view of the great effort by the engineers and administrators this medical evidence strikes a discordant note, for it seems only reasonable to conclude that either the present level of " approved" conditions is too high for these coal-faces or that " approved" conditions were not actually achieved in some of them. It would be very wrong to assume that the present standard of " approved " conditions is unsatisfactory without the fullest investigation of the other possibility. Such an investigation has actually been undertaken by the National Coal Board, who have been of the greatest help in these investigations and have already taken action on some smaller points as they were brought to their attention during the course of the work.

Such a long-term study could not be completed without the co-operation of a very large number of people. To mention all would be impossible; to mention some would be invidious. I can only express my gratitude to everyone concerned.

\section{REFERENCES}

Attygalle, D., Harrison, C. V., King, E. J., and Mohanty, G. P. (1954). Brit. J. industr. Med., 11, 245.

Cochrane, A. L. (1954) Brit, J. Tuberc, 48, 274.

-, Cox, J. G., and Jarman, T. F. (1952). Brit. med. J., 2, 843.

二, Cox, J. G., and Jarman, T. F. (1955). ibid., 1, 371

Davies, I., Chapman, P. J., and Rae, S. (1956). Brit. J. industr. Med., 13, 231.

and Miall, W. E. (1956). Brit, med. J., 1, 1193

二, and Miall, W. E. (1956). Brit. Med. J., 1, 1193. 72.

Fay, J. W. J., and Tomlinson, R. C. (1959). Geol. en Mijnb., 21, 320. [In English.]

Gough, J. (1959). In Modern Trends in Pathology, ed. D. H. Coilins, Chapter 14, pp. 273-299. Butterworth, London.

Gross, P., Westrick, M. L., and McNerney, J. M. (1957). Amer. J. Path., 33, 608.

International Latour Organization (1953). Third international conference of experts on pneumoconiosis, Sydney, 1950. Record of Proceedings, Vol. 1, page 104. 
-, (1959). Occup. Safety Hlth., 9, 63.

Jarman, T. F. (1953). Brit. med. J., 1, 754.

Rivers, D., Wise, M. E., King, E. J., and Nagelschmidt, G. (1960). Brit. J. industr. Med., 17, 87. King, E. J., Harrison, C. V., Mohanty, G. P., and Mitchison, D. A. Maguire, B. A., and Nagelschmidt, G. (1956). Brit. J. industr.

Vaccarezza, R. F. (1958). Proc. 5th Int. Congr. on Diseases of the

Vigliani, E. C., and Pernis, B. (1958). Brit. J. industr. Med., 15, 8. Watson, A. J., Black, J., Doig, A. T., and Nagelschmidt, G.'(1959).

Yoganathan, M., Harrison, C. V., and Mitchison, D. A (1957). A.M.A. Arch. industr. Hlth, 16, 380.

Rees, W. L., and Eysenck, H. J. (1945). J. ment. Sci., 91, 8. Zaidi, $\begin{aligned} & \text { S. H., Harrison, C. V., King, E. J., and Mitchison, D. A. } \\ & \text { (1955). Brit. J. exp. Path., 36, 539, 545, 553. }\end{aligned}$ 